\title{
Oil-based preservative materials for protection of copper against corrosion in atmospheres containing $\mathrm{SO}_{2}$
}

\author{
V. I. Vigdorovich, ${ }^{1}$ N. V. Shel, ${ }^{2}$ L. E. Tsygankova, ${ }^{* 3}$ and P. N. Bernatsky ${ }^{3}$ \\ ${ }^{1}$ Russian Scientific Research Institute of Use of Machinery and Oil Products, Novo- \\ Rubezhnyi per., 28, Tambov, 392022, Russian Federation \\ ${ }^{2}$ Tambov State Technical University, Sovetskaya Str., 106, Tambov, 392000, \\ Russian Federation \\ ${ }^{3}$ Derzhavin State University, Internatsyonalnaya Str., 33, Tambov, 392000, \\ Russian Federation \\ *E-mail:vits21@mail.ru
}

\begin{abstract}
The protective efficiency of oil coatings modified by a gun lubricant against copper corrosion in an atmosphere containing sulfur dioxide (up to 5 vol.\%) has been studied. The influence of the oil nature, additive concentration, relative humidity (70-100\%) and equilibrium $\mathrm{SO}_{2}$ concentration in the air was investigated. The protective effect of the formulations is up to $90 \%$ under particularly corrosive conditions.
\end{abstract}

Key words: preservative materials, protective effect, oil, copper, corrosion, sulfur dioxide, humidity, gun lubricant, electrode process, polarization, impedance.

Received: May 25, 2015.

doi: $\underline{10.17675 / 2305-6894-2015-4-3-210-220}$

\section{Introduction}

Atmospheric corrosion of metals has been intensely studied by scientists for many decades. Its kinetics and mechanism as a function of many factors - metal nature, relative air humidity, nature and concentration of cathodic depolarizers $\left(\mathrm{O}_{2}, \mathrm{SO}_{2}\right)$ - have been considered and generalized in monographs $[1,2]$. At the same time, this multifactor process is so complicated and the material, economic and ecologic damage caused by it is so considerable that its intense studies continue at present. It was noted already in [2] that $\mathrm{SO}_{2}$ present in the air is an efficient promoter of metal atmospheric corrosion. Subsequently, this fact was confirmed many times and the synergetic effect of $\mathrm{SO}_{2}$ and relative air humidity was shown [2-4]. It was shown that $\mathrm{SO}_{2}$ was an efficient cathodic depolarizer [4]. Later the problems of $\mathrm{SO}_{2}$ effect as a micro component of air stimulating the corrosion of ferrous and non-ferrous metals were broadly studied $[5,6]$. In the initial approaches, the simplest correlation of metal losses $(m)$ and $\mathrm{SO}_{2}$ concentration was used [6]:

$$
m=A_{1}+A_{2}\left[\mathrm{SO}_{2}\right],
$$


where $A_{i}$ are constants (here and below). Subsequently, more complicated relationships were obtained [7]:

$$
\begin{gathered}
m=A_{1}+A_{2}\left[\mathrm{SO}_{2}\right]+A_{3}[\mathrm{TVK}] \\
m=A_{1}+A_{2}\left[\mathrm{Cl}^{-}\right]+A_{3}[\mathrm{TVK}] \\
m=A_{1}+A_{2}\left[\mathrm{SO}_{2}\right]+A_{3}\left[\mathrm{Cl}^{-}\right]+A_{4}[\mathrm{TVK}]
\end{gathered}
$$

Here $\left[\mathrm{Cl}^{-}\right]$is the rate of sedimentation of chloride ions in the salt composition, $\mathrm{mg} /\left(\mathrm{m}^{2} \cdot \mathrm{yr}\right)$, and TVK is the composite climate index. A summary of analytic relationships of this kind is given in [6]. An expanded summary of analytic relationships for carbon steel, $\mathrm{Cu}, \mathrm{Al}$, and $\mathrm{Zn}$, including information about similar equations developed in other countries based on data from 73 corrosion stations, is provided in [7]. A number of new results obtained in recent years was published in [8-10]. The data obtained indicate the necessity of efficient protection of metals against atmospheric corrosion. Some data of this kind characterizing the efficiency of protective coatings based on fresh and waste petroleum oils, individual alkanes, and waste products of vegetable oils production are generalized in $[11,12]$. In [13] the efficiency of oil coatings based on colza oil containing emulgin as anticorrosion additive against carbon steel corrosion in air atmosphere with heightened $\mathrm{SO}_{2}$ content is considered.

The aim of this manuscript is to present data on copper protection against corrosion in air containing $\mathrm{SO}_{2}$ in the wide range of equilibrium concentrations of the latter.

\section{Experimental}

Corrosion tests were conducted in sealed desiccators with relative air humidity $(H, \%)$ caused by saturated salt solutions at $20^{\circ} \mathrm{C}: \mathrm{NH}_{4} \mathrm{Cl}+\mathrm{KNO}_{3}(H=71.2) ; \mathrm{NH}_{4} \mathrm{Cl}(H=79.5)$; $\mathrm{ZnSO}_{4} \cdot 7 \mathrm{H}_{2} \mathrm{O}(\mathrm{H}=90) ; \mathrm{H}_{2} \mathrm{O}(100)$. Samples of $\mathrm{M} 1$ copper $(99.94 \%)$ with $30 \times 25 \times 3 \mathrm{~mm}$ dimensions were polished, washed with acetone and weighed. Then they were immersed for 1-2 minutes in a preservative bath and were left in vertical suspended state for a day to let the excess protective formulation to flow down. The thickness of the protective film of the preservative material was estimated gravimetrically according to the formula:

$$
h=10^{4} \Delta m /(\rho S),
$$

where $S$ is the visible sample surface; $\Delta m$ and $\rho$ are the mass and specific density of the protective formulation, respectively. Protective formulations were prepared from industrial oil I-20A, filtered waste motor oil (FWMO), unrefined colza oil (CO), and diesel fuel (DF) containing up to $40 \mathrm{wt} . \%$ gun lubricant (GL) as a thickening agent and corrosion inhibitor. Filtered waste motor oil (FWMO) was obtained after addition of carbamide to waste motor oil and formation of a precipitate.

The protective effect of preservative material coatings $(Z, \%)$ was calculated according to the formula:

$$
Z=100\left(K_{0}-K\right) / K_{0},
$$


where $K_{0}$ and $K$ are the copper corrosion rates without and with a protective coating.

$\mathrm{SO}_{2}$ was obtained by the reaction:

$$
\mathrm{Na}_{2} \mathrm{SO}_{3}+\mathrm{H}_{2} \mathrm{SO}_{4 \text { (conc) }} \rightarrow \mathrm{Na}_{2} \mathrm{SO}_{4}+\mathrm{H}_{2} \mathrm{O}+\mathrm{SO}_{2}
$$

in the device shown in Figure 1.

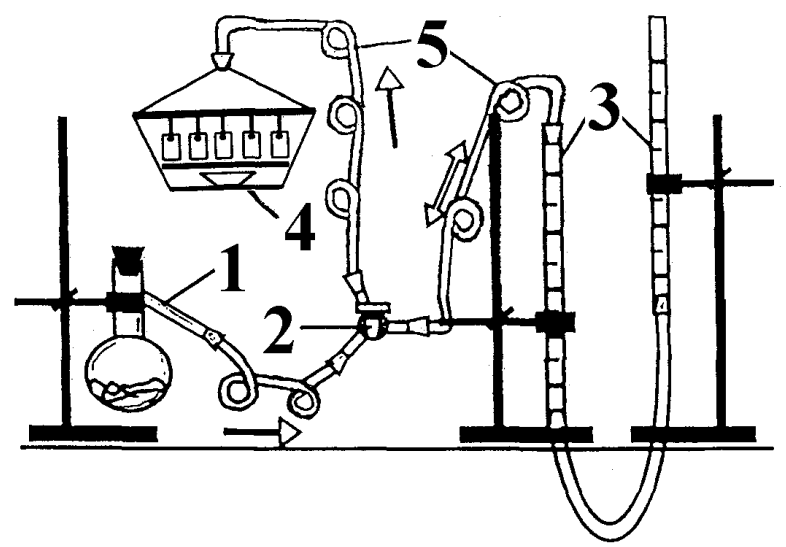

Figure 1. Device for $\mathrm{SO}_{2}$ synthesis and injection to a desiccator. 1 - retort for $\mathrm{SO}_{2}$ synthesis; 2 - distributive tap; 3 - $\mathrm{SO}_{2}$ measuring accumulator; 4 - desiccator or electrochemical cell; 5 - glass spring.

Potentiostatic polarization measurements were conducted in a three-electrode cell (Pyrex) with divided anode and cathode spaces in $0.5 \mathrm{M} \mathrm{NaCl}$ solution with an $\mathrm{Ag}, \mathrm{AgCl}$ saturated reference electrode and a Pt counter electrode. The potentials were brought to the standard hydrogen scale.

Electrochemical impedance spectroscopy measurements (Solartron 1250 FRA) were carried out in a frequency range of $10 \mathrm{kHz}-50 \mathrm{mHz}$ in a $0.5 \mathrm{M} \mathrm{NaCl}$ solution at the corrosion potential $\left(E_{\text {cor }}\right)$. The results obtained were processed using a program allowing to make calculations for any equivalent circuits with up to 20 elements.

The equivalent circuits (EC) shown in Figures $2 \mathrm{a}$ and $2 \mathrm{~b}$ were used as models for copper electrode impedance without a coating and with a coating, respectively, at $E_{\text {cor }}$. In the circuit shown in Figure $2 \mathrm{a}, R_{\mathrm{s}}$ is the solution resistance, $R_{\mathrm{a}}$ and $R_{\mathrm{c}}$ are the charge transfer resistances in the anodic and cathodic reactions, respectively; and $Z_{\mathrm{D}}$ is the generalized finite diffusion impedance of the depolarizer:

$$
Z_{\mathrm{D}}=R_{\mathrm{D}} \tanh (j \omega \tau)^{\mathrm{p}} /(j \omega \tau)^{\mathrm{p}},
$$

where $R_{\mathrm{D}}=R T \delta /\left(n^{2} F^{2} c_{\mathrm{S}} D\right)$ is the mass transfer resistance, $\tau=\delta^{2} / D$ is the characteristic diffusion time, $\delta$ is the diffusion layer thickness, $D$ is the diffusion coefficient, $C_{\mathrm{dl}}$ is the electrical double layer capacity, $0<p<1$. The $p \neq 0.5$ value is caused, for instance, by diffusion to an irregular surface [14]. In the circuit shown in Figure $2 \mathrm{~b}, C_{\mathrm{f}}$ and $R_{\mathrm{f}}$ are the capacity of the coating and the solution resistance in the coating pores, respectively. 

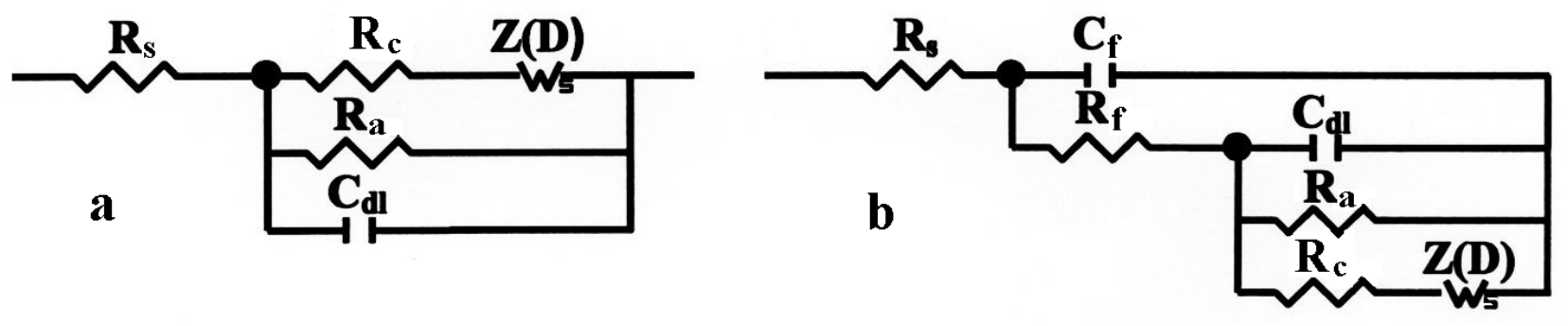

Figure 2. Equivalent circuits of copper electrode impedance without coating $(a)$ and with a composite oil coating $(b)$ at $E_{\text {cor. }}$.

\section{Results and discussion}

\section{Equilibrium $\mathrm{SO}_{2}$ concentration in a corrosive medium}

The equilibrium $\mathrm{SO}_{2}$ concentration differs essentially from initial one (Table 1). The $\mathrm{SO}_{2}$ content in the air of a desiccator is determined by $\mathrm{SO}_{2}$ solubility in the liquid phase and depends on the volume ratio of the gas $\left(V_{\text {gas }}\right)$ and liquid $\left(V_{\text {liq }}\right)$ phases, $V_{\text {gas }} / V_{\text {liq. }}$. An increase in $V_{\text {gas }}$ at $V_{\text {liq }}=$ const promotes a decrease in the difference between the initial $\mathrm{SO}_{2}$ concentration and the equilibrium one in the gas phase.

Table 1. $\mathrm{SO}_{2}$ concentration in the gas phase, $\mathrm{pH}$ of the liquid phase and concentration of the products of interaction between $\mathrm{SO}_{2}$ and $\mathrm{H}_{2} \mathrm{O}$ in aqueous film at $V_{\text {gas }} / V_{\text {liq }}=75$ and $20^{\circ} \mathrm{C}$.

\begin{tabular}{ccccc}
\hline$C_{\mathrm{SO}_{2} \text {, init }}$, vol. \% & $C_{\mathrm{SO}_{2}, \text { equil }}$, vol. \% & $\mathrm{pH}$ & $C_{\mathrm{H}_{2} \mathrm{SO}_{3}}, \mathrm{~mol} / \mathrm{L}$ & $C_{\mathrm{HSO}_{3}^{-}}, \mathrm{mol} / \mathrm{L}$ \\
\hline 1 & 0.40 & 1.96 & 0.007 & 0.011 \\
3 & 1.46 & 1.68 & 0.026 & 0.021 \\
5 & 2.58 & 1.56 & 0.045 & 0.028 \\
10 & 5.48 & 1.39 & 0.096 & 0.040 \\
20 & 10.60 & 1.30 & 0.147 & 0.074 \\
\hline
\end{tabular}

\section{Results of corrosion tests}

Individual oils and their blends with gun lubricant the concentration of which does not exceed 7 wt.\% increases the copper corrosion rate both in the absence (Figure 3 ) and in the presence of $\mathrm{SO}_{2}$ (Fig. 4). An increase in relative humidity stimulates copper corrosion (Figure 4). The same effect is observed upon increasing $\mathrm{SO}_{2}$ concentration (Figure 5).

In whole, gun lubricant is more perspective as an additive to colza oil and filtered waste motor oil with concentration equal to $40 \mathrm{wt}$. $\%$, when $Z$ of oil compositions reaches $92 \%$ and $86 \%$, respectively (the equilibrium $\mathrm{SO}_{2}$ concentration is 0.4 vol. $\%, H=70 \%$ ). 

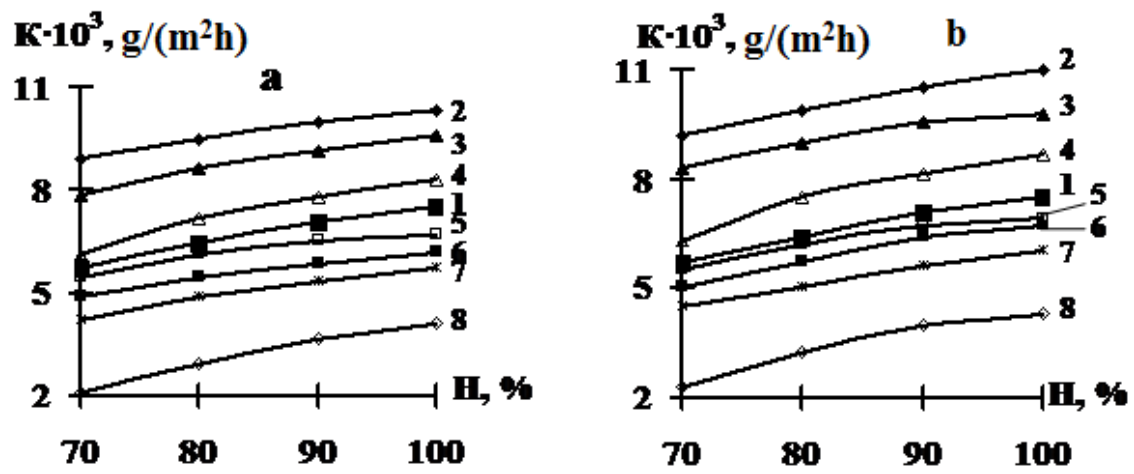

Figure 3. Dependence of copper corrosion rate $\left(\mathrm{g} /\left(\mathrm{m}^{2} \mathrm{~h}\right)\right.$ with protective oil formulations based on gun lubricant in colza oil $(a)$ and filtered waste motor oil $(b)$ on the relative air humidity $(H)$ in the absence of $\mathrm{SO}_{2}$. $C_{\mathrm{GL}}$, wt. $\%: 1-$ no coating; $2-0 ; 3-2 ; 4-5 ; 5-7 ; 6-$ $10 ; 7-20 ; 8-40$.
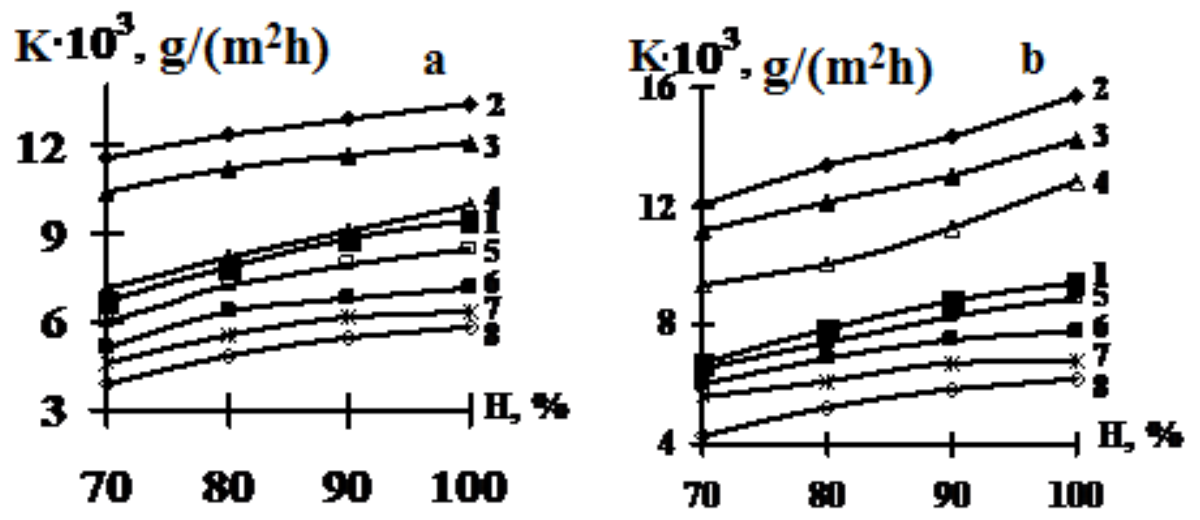

Figure 4. Dependence of copper corrosion rate $\left(\mathrm{g} /\left(\mathrm{m}^{2} \mathrm{~h}\right)\right.$ with protective oil formulations based on gun lubricant in colza oil $(a)$ and filtered waste motor oil $(b)$ on the relative air humidity $(H)$ with an equilibrium $\mathrm{SO}_{2}$ concentration of 0.4 vol.\%. $C_{\mathrm{GL}}$, wt. \%: 1 - no coating; $2-0 ; 3-$ $2 ; 4-5 ; 5-7 ; 6-10 ; 7-20 ; 8-40$.
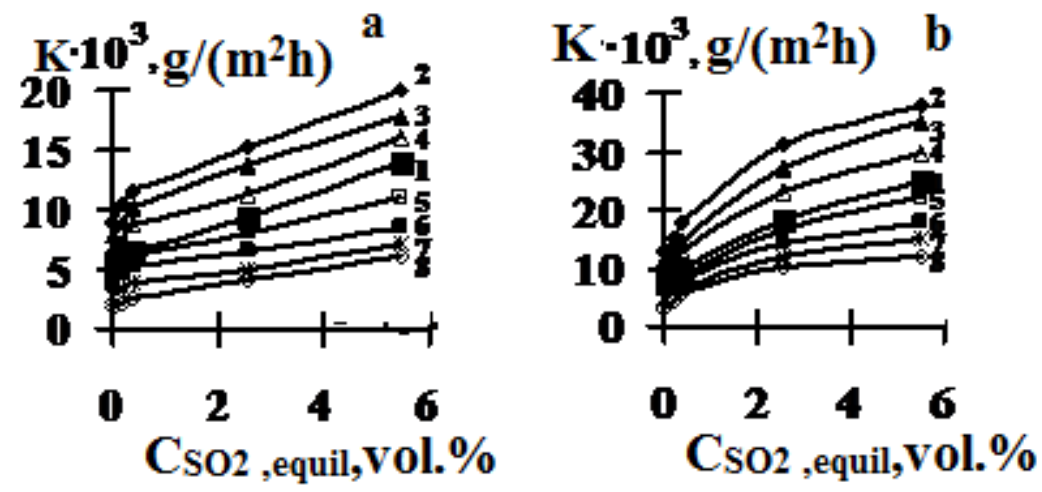

Figure 5. Dependence of copper corrosion rate $\left(\mathrm{g} /\left(\mathrm{m}^{2} \mathrm{~h}\right)\right.$ with protective oil formulations based on gun lubricant in diesel fuel on $\mathrm{SO}_{2}$ equilibrium volume concentration in air at a relative air humidity of $70 \%(a)$ and $100 \%(b) . C_{\mathrm{GL}}$, wt. \%: 1 - no coating; $2-0 ; 3-2 ; 4-5 ; 5-7 ; 6-$ $10 ; 7-20 ; 8-40$. 


\section{Kinetics of electrode processes}

It is known that the presence of $\mathrm{SO}_{2}$ in gas phase increases the rate of the cathodic process to strongly than that of the anodic process [2]. At that the corrosion potential and corrosion rate increase. The solution $\mathrm{pH}$ simultaneously decreases to 3...4. However, according to [3], the growth in hydrogen ion concentration in the presence of $\mathrm{SO}_{2}$ does not change the cathode process kinetics, because the limiting cathodic current density on hydrogen ions $i_{\text {limit }}$ is essentially smaller than the observed cathodic current density $i_{\text {cath }}$. The role of additional cathodic depolarizers belongs to $\mathrm{H}_{2} \mathrm{SO}_{3}$ and $\mathrm{HSO}_{3}^{-}$that form upon $\mathrm{SO}_{2}$ dissolution in water. The corresponding cathodic reactions are as follows [2]:

$$
\begin{gathered}
2 \mathrm{H}_{2} \mathrm{SO}_{3}+2 \mathrm{H}^{+}+4 \mathrm{e} \rightarrow \mathrm{S}_{2} \mathrm{O}_{3}^{2-}+3 \mathrm{H}_{2} \mathrm{O}, E^{0}=0.235 \mathrm{~V} \\
2 \mathrm{HSO}_{3}^{-}+2 \mathrm{H}^{+}+2 \mathrm{e} \rightarrow \mathrm{S}_{2} \mathrm{O}_{4}^{2-}+2 \mathrm{H}_{2} \mathrm{O}, E_{\mathrm{pH}=3}^{0}=0.195 \mathrm{~V}
\end{gathered}
$$

Use of thin inhibited oil coatings for protection of metals against atmospheric corrosion including industrial regions with high relative humidity and content of corrosion promoters is very efficient at present. However, their effect on the kinetics and mechanism of electrode reactions, in particular those involved in copper corrosion, has not been studied sufficiently. The $V_{\text {gas }} / V_{\text {liq }}$ value in the electrochemical cell is 1.4 , and the corresponding equilibrium $\mathrm{SO}_{2}$ concentration $\left(C_{\mathrm{SO}_{2}, \text { eq }}\right)$ in gas phase, equilibrium concentrations of $\mathrm{H}_{2} \mathrm{SO}_{3}$ and $\mathrm{HSO}_{3}^{-}$, and $\mathrm{pH}$ have been calculated (Table 2).

Table 2. Dependence of equilibrium concentrations of $\mathrm{SO}_{2}, \mathrm{H}_{2} \mathrm{SO}_{3}$ and $\mathrm{HSO}_{3}{ }^{-}$and $\mathrm{pH}$ on the initial $\mathrm{SO}_{2}$ concentration in the gas phase.

\begin{tabular}{|c|c|c|c|c|c|}
\hline$C_{\mathrm{SO}_{2} \text {, init }}$, vol. \% & $\begin{array}{c}C_{\mathrm{SO}_{2}, \text { equil }}, \mathrm{vol} . \\
\%\end{array}$ & $\mathrm{pH}$ & $\begin{array}{c}C_{\mathrm{H}_{2} \mathrm{SO}_{3}}, \\
\mathrm{mmol} / \mathrm{L}\end{array}$ & $C_{\mathrm{HSO}_{3}^{-}}, \mathrm{mmol} / \mathrm{L}$ & $C_{\mathrm{SO}_{3}^{2-}}, \mathrm{mmol} / \mathrm{L}$ \\
\hline $5 \cdot 10^{-5}$ & $7.6 \cdot 10^{-12}$ & 6.9 & $1.3 \cdot 10^{-10}$ & $1.9 \cdot 10^{-5}$ & $9.6 \cdot 10^{-6}$ \\
$5 \cdot 10^{-4}$ & $2.9 \cdot 10^{-10}$ & 6.5 & $5.0 \cdot 10^{-9}$ & $2.4 \cdot 10^{-5}$ & $4.2 \cdot 10^{-5}$ \\
$5 \cdot 10^{-3}$ & $2.7 \cdot 10^{-8}$ & 5.5 & $5.0 \cdot 10^{-7}$ & $2.8 \cdot 10^{-3}$ & $5.9 \cdot 10^{-5}$ \\
$5 \cdot 10^{-2}$ & $1.1 \cdot 10^{-7}$ & 5.2 & $1.9 \cdot 10^{-6}$ & $5.6 \cdot 10^{-3}$ & $6.1 \cdot 10^{-5}$ \\
$2 \cdot 10^{-2}$ & $2.7 \cdot 10^{-6}$ & 4.5 & $4.7 \cdot 10^{-5}$ & $2.8 \cdot 10^{-2}$ & $6.2 \cdot 10^{-5}$ \\
$1 \cdot 10^{-1}$ & $1.1 \cdot 10^{-5}$ & 4.2 & $1.9 \cdot 10^{-4}$ & $5.7 \cdot 10^{-2}$ & $6.2 \cdot 10^{-5}$ \\
0.5 & $2.6 \cdot 10^{-4}$ & 3.6 & $4.6 \cdot 10^{-3}$ & $2.8 \cdot 10^{-1}$ & $6.2 \cdot 10^{-5}$ \\
1.0 & $1.0 \cdot 10^{-3}$ & 3.3 & $1.8 \cdot 10^{-2}$ & $5.5 \cdot 10^{-1}$ & $6.2 \cdot 10^{-5}$ \\
3.0 & $8.1 \cdot 10^{-3}$ & 2.8 & $1.4 \cdot 10^{-1}$ & 1.6 & $6.2 \cdot 10^{-5}$ \\
5.0 & $2.0 \cdot 10^{-2}$ & 2.6 & $3.6 \cdot 10^{-1}$ & 2.5 & $6.2 \cdot 10^{-5}$ \\
10.0 & $6.7 \cdot 10^{-2}$ & 2.4 & 1.2 & 4.5 & $6.2 \cdot 10^{-5}$ \\
\hline
\end{tabular}


Anodic polarization curves of copper are characterized by an extensive Tafel section with $b_{\mathrm{a}}=0.055 \mathrm{~V}$. Cathodic polarization curves are characterized by a short linear section followed by a section with limiting current density on $\mathrm{O}_{2}\left(i_{\text {lim }}^{\text {cat }}\right)$. With $C_{\text {gun lubricant }}$ growth in the oil formulations (from 2 to $40 \mathrm{wt} . \%$ ), a decrease in the metal ionization rate and $i_{\lim }^{\text {cat }}$ is observed (Figure 6).

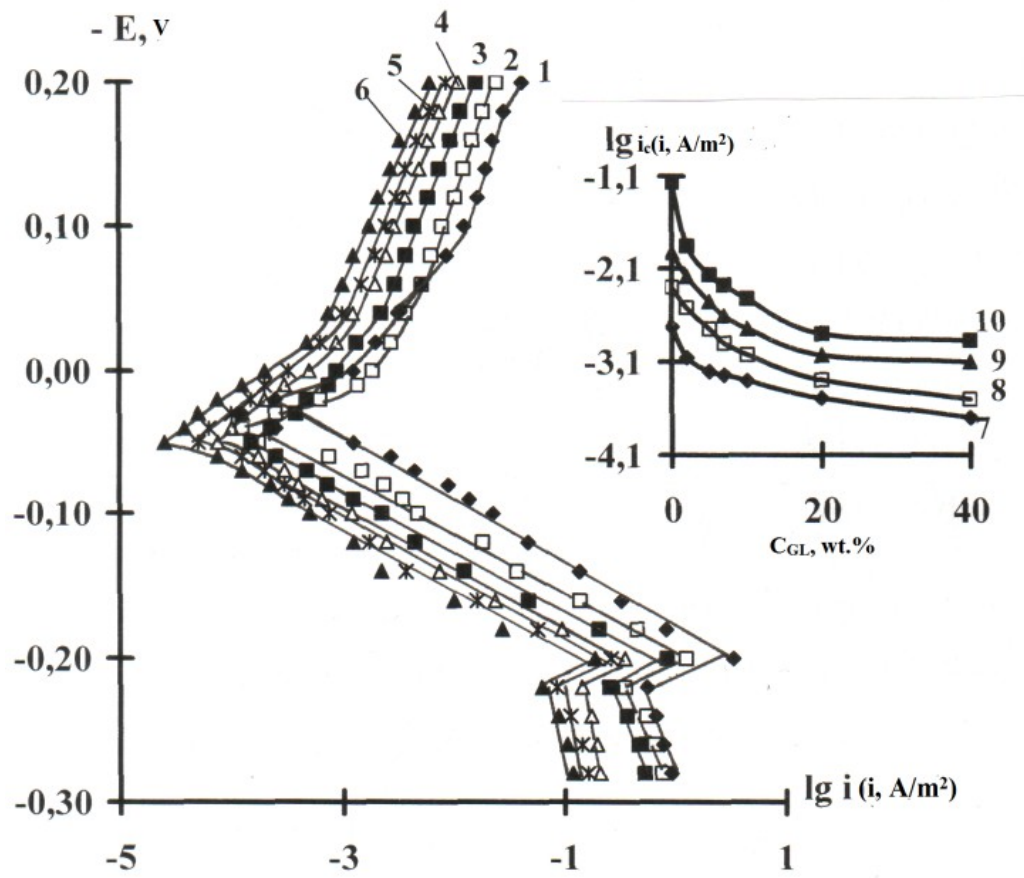

Figure 6. Cathodic (1-6) and anodic polarization curves of copper covered by protective film of the oil formulation containing gun lubricant in colza oil and dependence of limiting cathodic current density on $\mathrm{O}_{2}(7-10)$ versus $C_{\text {gun lubricant }}($ at $E=0)$ in various support

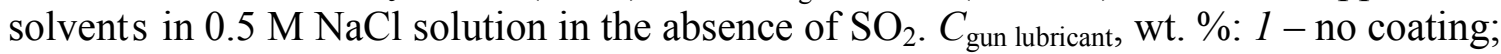
$2-0 ; 3-2 ; 4-10 ; 5-20 ; 6-40$. Support solvent: 7 - colza oil; 8 - filtered waste motor oil: 9 - diesel fuel; $10-$ I-20A.

The presence of a thin oil formulation coating on copper increases $E_{\text {cor }}$ by $0.01-$ $0.03 \mathrm{~V}$ (Figure 6).

Injection of $1.1 \cdot 10^{-5}$ vol. $\% \mathrm{SO}_{2, \mathrm{eq}}$ increases the rate of both cathodic and anodic reactions independently on the support solvent nature (Figure 7). A further increase in the equilibrium $\mathrm{SO}_{2}$ concentration accelerates the cathodic process even more.

The anodic polarization curves are parallel (Figure 7). This allows us to assume the absence of changes in the anodic process mechanism with an increase in $C_{\mathrm{GL}}$ and $C_{\mathrm{SO}_{2} \text {,eq }}$ in the gas phase. Retardation of both electrode reactions in the presence of oil formulation coating indicates, in first approximation, a decrease in the quantity of sulfur-containing particles near the electrode surface and difficulty of $\mathrm{O}_{2}$ and $\mathrm{SO}_{2}$ access to it because of the barrier layer of the protective film. The role of gun lubricant is identical in the presence 
and absence of $\mathrm{SO}_{2}$. Colza oil and filtered waste motor oil are the most promising support solvent because in the presence of their blends, the limiting cathodic current densities of $\mathrm{O}_{2}$ and copper dissolution rates are smaller than in the presence of formulations based on I$20 \mathrm{~A}$ and diesel fuel. In general, the rate of both partial electrode reactions depends on $C_{\mathrm{GL}}$ in the coating and $C_{\mathrm{SO}_{2}}$ in the atmosphere. Hindrance of the cathodic process increases with $C_{\mathrm{GL}}$ growth, independently on oil nature. Copper corrosion under thin oil formulation films occurs according to the electrochemical mechanism. The main contribution of gun lubricant to the protective effect results from hindrance of the anodic process.
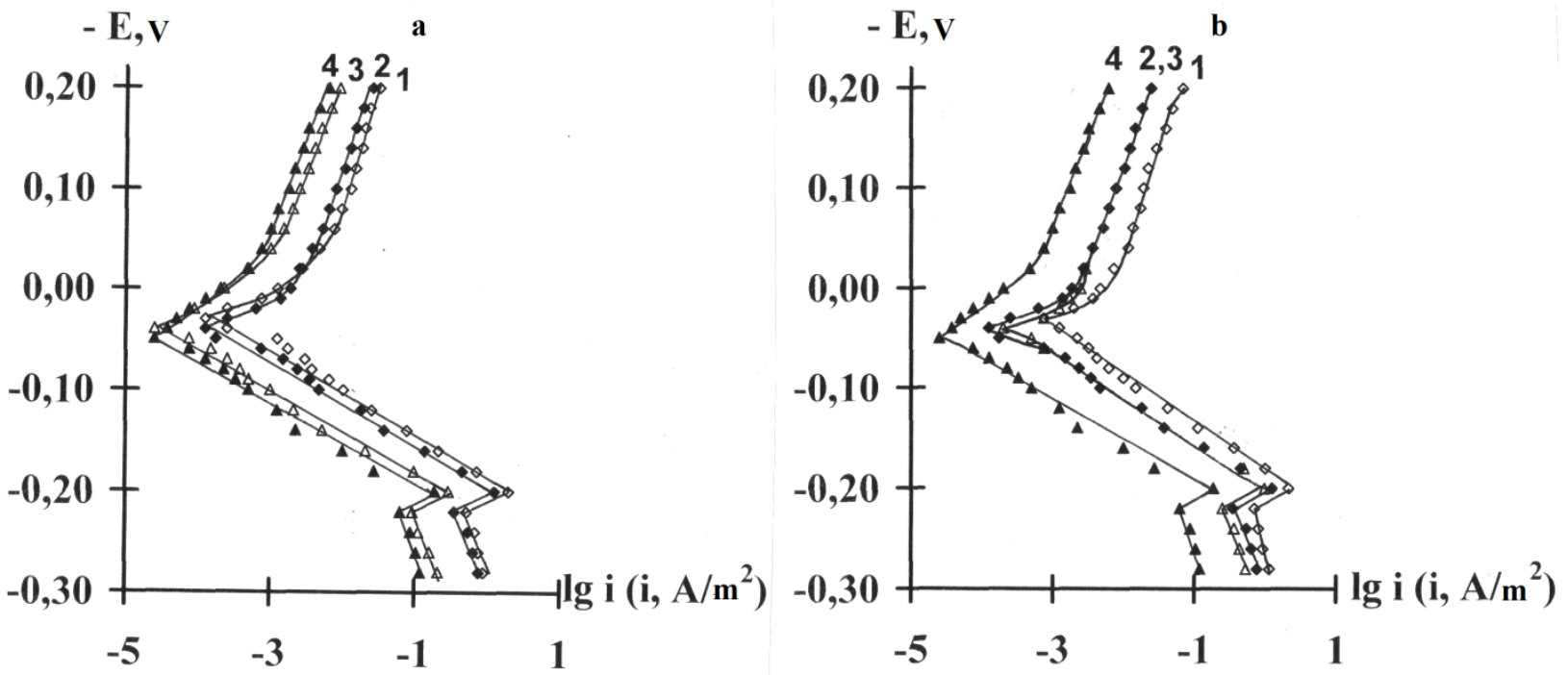

Figure 7. Cathodic (1-4) and anodic polarization curves of copper covered by a protective film of oil formulation containing gun lubricant in colza oil in $0.5 \mathrm{M} \mathrm{NaCl}$ solution. $1,2-$ colza oil; 3, 4-40 wt. \% gun lubricant in colza oil. a. 2,4 - without $\mathrm{SO}_{2} ; 1,3-1.1 \cdot 10^{-5}$ vol. $\% \mathrm{SO}_{2, \text { eq }} ; b .2,4$ - without $\mathrm{SO}_{2} ; 1,3-6.7 \cdot 10^{-2}$ vol. $\% \mathrm{SO}_{2, \text { eq }}$.

\section{Data of impedance spectroscopy}

The use of impedance spectroscopy method to characterize the protective properties of oil based coatings is not too widespread, but, according to experimental data $[15,16]$, is very informative.

The Nyquist diagrams of copper electrode obtained at $E_{\text {cor }}$ are shown in Figures 8 and 9. They are semicircles distorted in the low frequency region. In the presence of a coating the radius of the semicircle increases because of the charge transfer resistance increase, which is the more the higher $C_{\mathrm{GL}}$ in the formulation (Figures 8 and 9). The values of the elements of the equivalent circuits of Figure $1 \mathrm{~b}$ are shown in Table 3. 

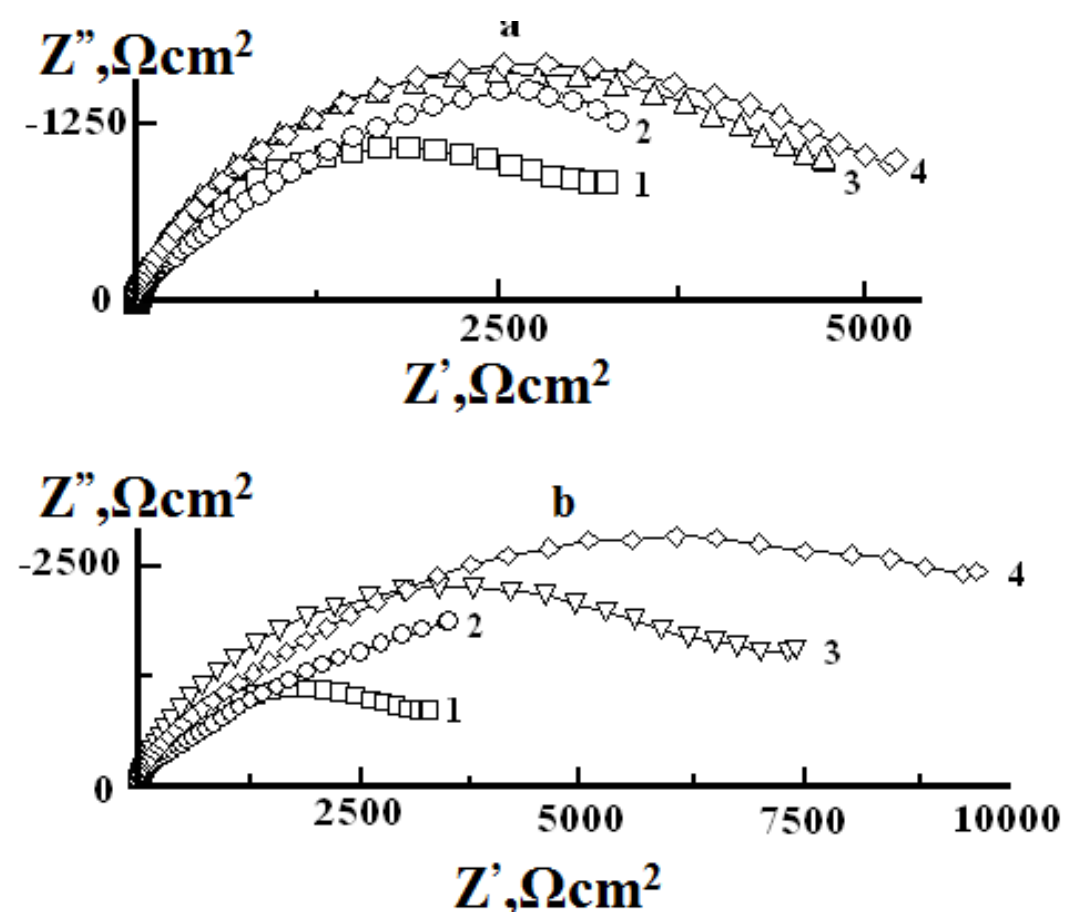

Figure 8. Nyquist diagrams of copper electrode covered by the oil formulation film based on gun lubricant in I-20A $(a)$ and filtered waste motor oil $(b)$ in $0.5 \mathrm{M} \mathrm{NaCl}$ solution. $C_{\mathrm{GL}}$, wt.\%: 1 - no coating; $2-0 ; 3-7 ; 4-40$. The experimental values are shown by dots; the lines correspond to the values calculated in accordance with the equivalent circuit.
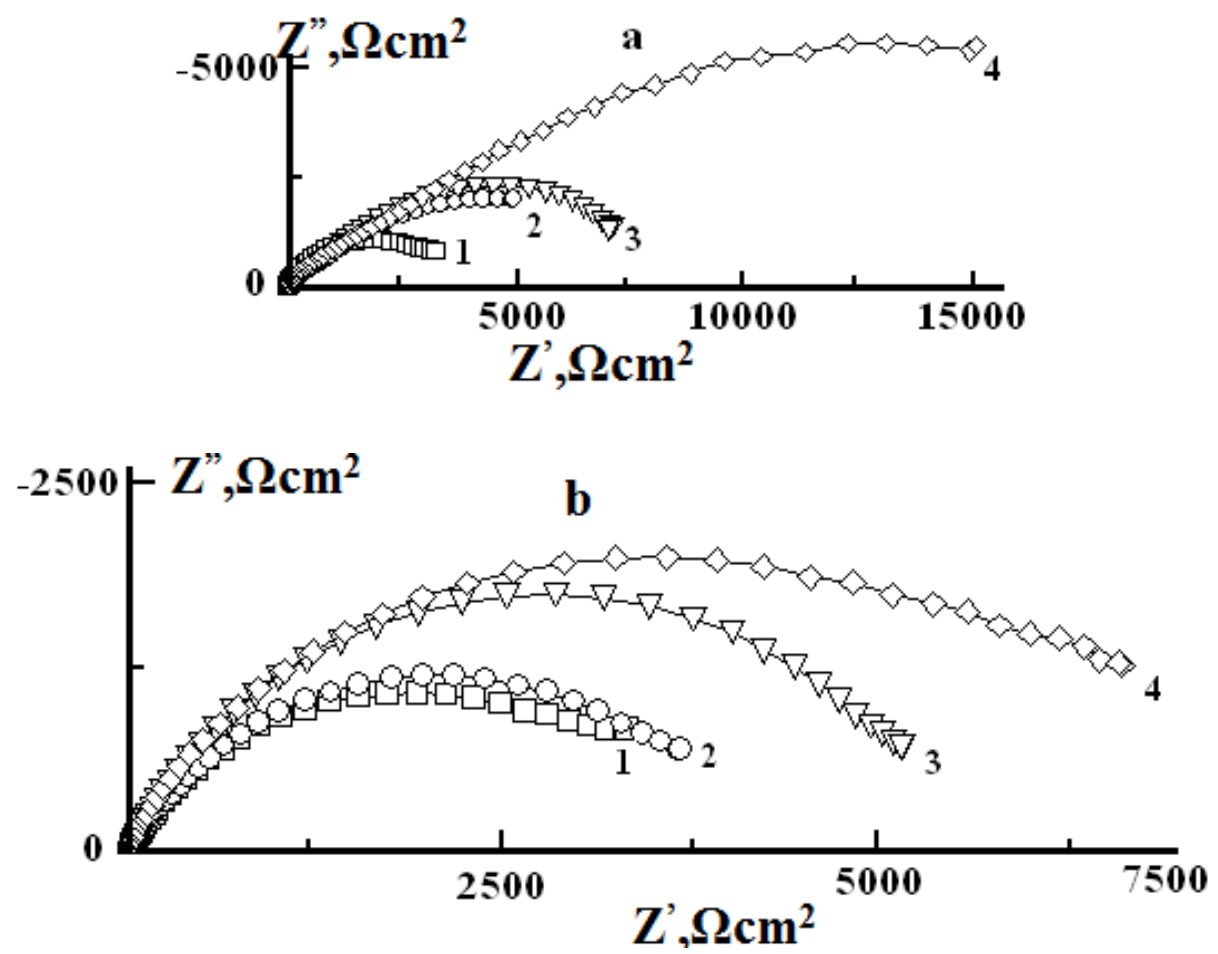

Figure 9. Nyquist diagrams of copper electrode covered by the oil formulation film based on gun lubricant in colza oil $(a)$ and diesel fuel $(b)$ in $0.5 \mathrm{M} \mathrm{NaCl}$ solution. $C_{\mathrm{GL}}$, wt.\%: 1 - no coating; $2-0 ; 3-7 ; 4-40$. The experimental values are shown by dots; the lines correspond to the values calculated in accordance with the equivalent circuit. 
Table 3. The values of the elements of the equivalent circuit of Figure 1 for copper without and with a coating in the $0.5 \mathrm{M} \mathrm{NaCl}$ solution.

\begin{tabular}{ccccccc}
\hline Coating & $\boldsymbol{C}_{\mathbf{f}}, \boldsymbol{\mu F} / \mathbf{c m}^{\mathbf{2}}$ & $\boldsymbol{R}_{\mathbf{f}}, \mathbf{\Omega} \cdot \mathbf{c m}^{\mathbf{2}}$ & $\boldsymbol{R}_{\mathbf{a}}, \mathbf{\Omega} \cdot \mathbf{c m}^{\mathbf{2}}$ & $\boldsymbol{R}_{\mathbf{c}}, \boldsymbol{\Omega} \cdot \mathbf{c m}^{\mathbf{2}}$ & $\boldsymbol{R}_{\boldsymbol{D}}, \mathbf{\Omega} \cdot \mathbf{c m}^{\mathbf{2}}$ & $\boldsymbol{p}$ \\
\hline Absent & - & - & 3799 & 347 & 40400 & 0.63 \\
I-20A & 32 & 138 & 4976 & 428 & 40850 & 0.52 \\
I-20A + 7 wt.\% GL & 18 & 290 & 5148 & 493 & 41450 & 0.59 \\
I-20A + 40 wt.\% GL & 12 & 292 & 5236 & 587 & 57350 & 0.61 \\
\hline FWMO & 6 & 129 & 6299 & 390 & 46140 & 0.40 \\
FWMO+ 7 wt.\% GL & 4 & 210 & 8610 & 438 & 70080 & 0.53 \\
FWM + 40 wt.\% GL & 3 & 406 & 11530 & 583 & 114730 & 0.56 \\
\hline DF & 15 & 170 & 4580 & 391 & 55350 & 0.63 \\
DF + 7 wt.\% GL & 6 & 241 & 5097 & 461 & 103980 & 0.51 \\
DF + 40 wt.\% GL & 4 & 315 & 7464 & 556 & 131230 & 0.62 \\
\hline CO & 9 & 125 & 6731 & 350 & 41210 & 0.53 \\
CO + 7 wt.\% GL & 4 & 223 & 8918 & 355 & 43042 & 0.45 \\
CO + 40 wt.\% GL & 0.4 & 276 & 31989 & 386 & 51580 & 0.53 \\
\hline
\end{tabular}

The finite diffusion impedance of oxygen as a sole cathodic depolarizer exceeds the charge transfer resistance of anodic $\left(R_{\mathrm{a}}\right)$ and cathodic $\left(R_{\mathrm{c}}\right)$ reactions 6..12-fold and $95 . .140$-fold, respectively (in the absence of $\mathrm{SO}_{2}$ and protective coating). Thus, copper corrosion rate is controlled by diffusion of the cathodic depolarizer. The presence of an oil film without a filler increases the values of $R_{\mathrm{D}}, R_{\mathrm{a}}$ and $R_{\mathrm{c}}$ but almost does not change the $R_{\mathrm{D}} / R_{\mathrm{i}}$ ratio. However, the charge transfer resistance in the anodic reaction is larger than $R_{\mathrm{c}}$ by nearly one order of magnitude. Consequently, the barrier oil layer does not affect the cathodic reaction kinetics in the absence of $\mathrm{SO}_{2}$. A similar picture is observed for $R_{\mathrm{a}}$.

Incorporation of $7 \mathrm{wt} \% \%$ gun lubricant to the oils decreases $C_{\mathrm{dl}}$. Increasing the $C_{\mathrm{GL}}$ up to $40 \mathrm{wt} . \%$ does not change the observed picture qualitatively. In case of DF and FWMO, $R_{\mathrm{D}}$ increases more essentially than $R_{\mathrm{a}}$ and certainly $R_{\mathrm{c}}$ (Table 3 ). The results of impedance measurements confirm that the compositions based on FWMO are characterized by a better protective efficiency than those based on I-20A, because $R_{\mathrm{a}, \mathrm{FWMO}}>R_{\mathrm{a}, \mathrm{I}-20 \mathrm{~A}}$ and $R_{\mathrm{D}, \mathrm{FWMO}}>$ $R_{\mathrm{D}, \mathrm{I}-20 \mathrm{~A}}$. Thus, incorporation of gun lubricant increases the charge transfer resistance in the anodic reaction and $R_{\mathrm{D}}$ of oxygen transfer (in the absence of $\mathrm{SO}_{2}$ in the gas phase).

\section{Conclusion}

The preservative materials based on gun lubricant and colza oil and filtered waste motor oil are sufficiently efficient against copper corrosion under particularly severe conditions at high $\mathrm{SO}_{2}$ concentrations. Under such conditions, oil composition coatings containing $40 \mathrm{wt} . \%$ gun lubricant decrease the copper corrosion rate $12 \ldots 7$-fold at protective film thicknesses of $260 \mu \mathrm{m}$ (colza oil) ... $550 \mu \mathrm{m}$ (FWMO), respectively. 
Colza oil and filtered waste motor oil are more promising support solvents for preparation of protective formulations against copper corrosion in atmospheres containing $\mathrm{SO}_{2}$. The optimum concentration of gun lubricant in the protective formulation is $40 \mathrm{wt} . \%$.

\section{References}

1. N. D. Tomashov, Teoriya korrozii i zaschity metallov (Theory of corrosion and metal protection), Moscow, 1959 (in Russian).

2. I. L. Rozenfeld, Atmosfernaya korroziya metallov (Atmospheric corrosion of metals), AN SSSR, Moscow, 1960 (in Russian).

3. I. L. Rozenfeld and V. P. Persiyantseva, Ingibitory atmosfernoi korrozii (Inhibitors of atmospheric corrosion), Nauka, Moscow, 1965 (in Russian).

4. I. L. Rosenfeld and T. I. Lukonina, Dokl. Akad. Nauk SSSR, 1956, 111, no. 1, 136 (in Russian).

5. Yu. N. Mikhailovsky, P. V. Strekalov and V. V. Agafonov, Zashch. Met., 1980, 16, no. 4, 396 (in Russian).

6. Yu. N. Mikhailovsky and P. V. Strekalov, Korroz.: Mater., Zashch., 2006, no. 3, 2 (in Russian).

7. R. Landolfo, L. Cascini and F. Portioli, Sustainability, 2010, no. 2, 2163. doi: $10.3390 /$ su2072163

8. Yu. M. Vaparov, A. D. Zhirkov, E. N. Mischenko, S. A. Karimova, S. V. Panin, O. A. Dobryanskaya and T. I. Tarapaeva, Korroz.: Mater., Zashch., 2010, no. 5, 1 (in Russian).

9. Yu. M. Panchenko, P. V. Strekalov and T. V. Nikulina, Korroz.: Mater., Zashch., 2013, no. 2, 9 (in Russian).

10. Yu. M. Panchenko, P. V. Strekalov and T. V. Nikulina, Korroz.: Mater., Zashch., 2013, no. 3, 1 (in Russian).

11. V. I. Vigdorovich, L. E. Tsygankova and N. V. Shel, Vestnik Tambovskogo Universiteta, Natural and Technical Sciences, 2014, 19, no. 1, 153 (in Russian).

12. V. I. Vigdorovich, L. E. Tsygankova, N. V. Loktionov and N. V. Shel, Int. J. Corros. Scale Inhib., 2013, 2, no. 2, 115. doi: 10.17675/2305-6894-2013-2-2-115-121

13. N. V. Shel, P. N. Bernatsky, V. I. Vigdorovich, L. E. Tsygankova, Yu. V. Panfilova and A. Yu. Antsupova, Praktika protivokorrozionnoi zashchity, 2014, 73, no. 3, 62 (in Russian).

14. T. Pajkossy and L. Nyikos, Electrochim. Acta, 1989, 34, 171.

15. L. E. Tsygankova, V. I. Vigdorovich, V. I. Kichigin and Ya. R. Kim, ECS Trans., 2008, 18, no. 11, 11.

16. L. E. Tsygankova, V. I. Vigdorovich, Ya. R. Kim and V. I. Kichigin, Korroz.: Mater., Zashch., 2008, no. 1, 37 (in Russian). 